\title{
Penjadwalan Waktu Istirahat Optimal Untuk Mengurangi Risiko Musculoskeletal Disorders Berdasarkan OCRA Index
}

\author{
Debrina Puspita Andriani ${ }^{1}$, Sugiono ${ }^{2}$
}

\begin{abstract}
Repetitive tasks carried out by workers of packaging department of mineral water company led to some complaints of pain and fatigue on a particular body part of the workers, especially on their upper body part. This study aims to determine risk level of musculoskeletal disorders with OCRA index and provides optimal break schedule to reduce the risk level. Based on calculations using the OCRA index method, it is found that risk of injury to the workers were medium with high level of risk. Despite small workload of the operators, this may be caused by poor distribution of rest periods and lengthy working time for highly repetitive tasks. Improvement proposed in this study is type of work-compliant break time allocation. Optimal scheduling of which main objective is optimal break time is eventually obtained by applying enumeration algorithm with integer linear programming model. Based on OCRA index after improvement, it is clear that the proposal decreases the risk level of the workers.
\end{abstract}

Keywords. break schedule, muscoloskeletal disorders, repetitive task, OCRA index, integer linear programming

\begin{abstract}
Abstrak. Pekerjaan repetitif yang dilakukan oleh pekerja pada bagian packaging di perusahaan air mineral memunculkan beberapa keluhan sakit dan kelelahan pada bagian tubuh tertentu, terutama pada bagian atas tubuh. Artikel ini membahas level risiko muscoloskeletal disorders dengan OCRA indexdan memberikan penjadwalan waktu istirahat yang optimal untuk mengurangi level risiko tersebut.Risiko cidera operator bagian packaging adalah sedang dan tinggi yang disebabkan masih buruknya distribusi waktu istirahat yang belum sesuai dan waktu bekerja yang terlalu lama untukjenis pekerjaan yang mempunyai sifat repetitif yang sangat tinggi, meskipun beban kerjanya kecil. Usulan perbaikannya adalah alokasi waktu istirahat sesuai dengan jenis pekerjaan. Penjadwalan yang optimal dilakukan dengan enumerative algorithm melalui model integer linear programming yang mampu memberikan jadwal istirahat yang optimal. Hasil perhitungan nilai OCRA index usulan diketahui menurunkan nilai level risiko untuk operator dibandingkan nilai level risiko sebelumnya.
\end{abstract}

Kata kunci. jadwal istirahat, muscoloskeletal disorders, pekerjaan repititif, OCRA index, integer linear programming

\section{Pendahuluan}

Kegiatan produksi dalam suatu perusahaan tidak lepas dari interaksi antara manusia dengan mesin atau fasilitas yang digunakan. Dalam kaitannya dengan ilmu ergonomi, suatu proses produksi dapat dikatakan mempunyai nilai

\footnotetext{
Debrina Puspita Andriani, Jurusan Teknik Industri Universitas Brawijaya, J1. MT. Haryono 167 Malang, 65145. (email: debrina@ub.ac.id)

${ }^{2}$ Sugiono, Jurusan Teknik Industri Universitas Brawijaya Jl. MT. Haryono 167 Malang, 65145
}

Diajukan: 09-10-2016 Disetujui: 20-12-2016

Diperbaiki: 31-11-2016 ergonomi apabila mesin atau fasilitas yang digunakan secara faal, antropometri, biomekanika dan fisiologisnya sesuai dengan manusia atau operatornya. Kegiatan produksi terdiri dari berbagai macam aktivitas, salah satunya adalah kegiatan yang mempunyai sifat berulang (repetitive task).

Di dunia industri, repetitive task merupakan faktor risiko ergonomi terpenting dalam banyak jenis pekerjaan. Faktor risiko dari kegiatan tersebut sering didefinisikan sebagai penyebab sindrom repetitive strain injuries (RSI). Menurut Silverstein (2007), tingkat pengulangan yang tinggi didefinisikan berlangsung dalam siklus durasi kurang dari 30 detik. Pengulangan yang tinggi terjadi ketika lebih dari $50 \%$ dari waktu siklus dihabiskan untuk melakukan jenis aktivitas 
teknis yang sama. Perlu diperhatikan bahwa siklus yang pendek biasanya tidak memerlukan gerak tubuh yang sering, sedangkan siklus yang panjang melibatkan gerak tubuh dalam frekuensi tinggi. Oleh karena itu, frekuensi gerak tubuh menjadi faktor penting dalam melakukan penilaian risiko untuk tugas berulang.

Perusahaan yang menjadi obyek pada penelitian ini merupakan perusahaan yang bergerak di bidang industri air mineral. Dalam proses produksinya, terdapat aktivitas kerja yang mempunyai sifat berulang atau repetitive. Salah satunya adalah pada proses di bagian packaging. Pada bagian packaging di perusahaan ini terdapat empat orang operator yang dibagi menjadi dua workstation kerja, dimana setiap harinya bekerja mulai pukul 07.30 sampai dengan 15.30 atau setara dengan delapan jam kerja. Rata-rata dalam satu hari operator pada bagian packaging dapat menghasilkan lebih kurang 1.600 box air mineral.

Dari hasil wawancara yang dilakukan pada semua operator bagian packaging, diketahui bahwa pekerjaan yang dilakukan selama ini sering menimbulkan keluhan sakit dan kelelahan pada bagian tubuh tertentu, terutama pada bagian leher, pundak, bahu, tangan dan punggung, atau bagian-bagian atas tubuh, dimana keluhan tersebut hampir dirasakan oleh operator setiap hari. Menurut Mossa, dkk. (2016), adanya keluhan-keluhan yang dirasakan oleh para operator tersebut mengindikasikan bahwa sistem kerja yang dilakukan belum merupakan sistem kerja yang terbaik, sehingga nantinya dapat berpengaruh pada tingkat produktivitas para karyawan.

Selama ini, permasalahan tersebut belum menjadi perhatian khusus dari pihak manajemen perusahaan yang ditunjukkan dengan belum adanya kegiatan evaluasi dan perbaikan sistem kerja yang telah diterapkan. Oleh karena itu, diperlukan suatu metode untuk menganalisis kondisi operator, khususnya kondisi postur kerja dengan adanya aktivitas berulang yang dialami oleh operator pada bagian packaging.

Ada beberapa metode untuk menganalisis risiko postur kerja. Salah satu yang sesuai digunakan untuk mengidentifikasi masalah pekerjaan yang mempunyai sifat berulang adalah metode occupational repetitive action (OCRA) index (Chiasson, dkk., 2012; Roman-Liu, 2014; Occhipinti \& Colombini, 2016). OCRA index merupakan metode kuantitatif yang digunakan untuk mengidentifikasi cara kerja pada pekerjaan berulang yang terutama menimbulkan risiko pada alat gerak tubuh bagian atas. Metode ini telah digunakan sebagai alat analisis aktivitas berulang pada suatu bagian produksi. Penerapan metode OCRA index dapat mengurangi risiko masalah ergonomi dan gangguan musculoskeletal pada operator yang mengalami beberapa keluhan kerja (Roossary \& Muslim, 2007). Metode OCRA index dapat membantu menganalisis postur dan gerakan kerja pada operator (Prasetyo, 2010).

Beberapa penelitian lainnya, seperti yang dilakukan oleh Marian, dkk. (2006), Choi (2009), $\mathrm{Xu}$, dkk. (2011), Otto dan Scholl (2011), serta Boenzi, dkk. (2013), telah mengembangkan berbagai model integer linear programming untuk melakukan penjadwalan terhadap waktu istirahat pada jenis pekerjaan yang berbeda-beda dengan tujuan untuk mengurangi adanya RSI. Seringkali dalam penelitian terdahulu, kegiatan evaluasi ergonomi dan penjadwalan pekerjaan dianalisis secara terpisah.

Dalam penelitian ini, setelah dilakukan analisis kondisi operator packaging air mineral dengan metode OCRA index, berikutnya dilakukan penjadwalan waktu istirahat untuk mengurangi risiko kelelahan kerja. Berdasarkan nilai awal hasil evaluasi dengan OCRA index yang berupa nilai indeks level risiko dan potensi risiko musculoskeletal disorders, artikel ini membahas pengurangan potensi risiko dengan penjadwalan waktu istirahat yang optimal.

\section{Metodologi}

Artikel ini disusun dengan menggunakan metode penelitian evaluatif. Penelitian evaluatif merupakan penelitian yang melakukan evaluasi permasalahan dari keadaan suatu objek sehingga didapatkan solusi permasalahan berupa usulan perbaikan (Sugiyono, 2012). 


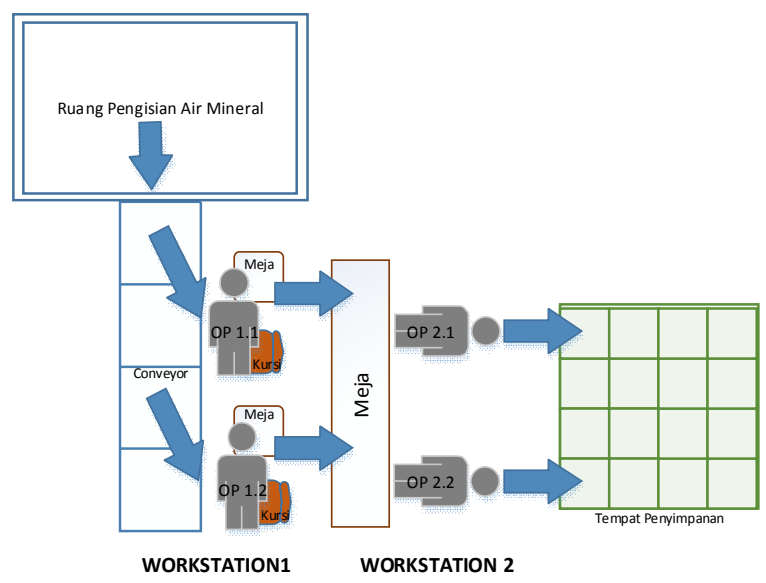

Gambar 1. Denah stasiun kerja operator workstation 1 dan 2

Pada tahap pengumpulan data, data diperoleh berdasarkan hasil pengamatan atau pengukuran secara langsung terhadap objek penelitian. Data tersebut meliputi data keluhan operator dan data waktu siklus pada bagian packaging. Data keluhan operator diperoleh melalui wawancara dengan seluruh operator sejumlah empat orang, sedangkan data waktu siklus diperoleh melalui pengamatan langsung dengan mengukur waktu kerja menggunakan stopwatch. Waktu siklus adalah waktu yang dibutuhkan operator untuk menyelesaikan satu kali proses pekerjaanya.

Pada stasiun kerja packaging terdapat dua workstation, yaitu workstation 1 dan workstation 2. Pada masing-masing workstation terdapat dua orang operator dan mempunyai tugas yang berbeda antar tiap workstation. Pada operator workstation 1 terdapat 2 orang operator yang bekerja dengan duduk dan menghadap meja untuk memasukkan air mineral gelas yang disalurkan melalui conveyor yang ada disamping kiri operator ke dalam kardus yang telah diletakkan di atas meja. Sedangkan pada workstation 2 juga terdapat 2 orang operator yang bekerja dengan berdiri menghadap meja untuk melakukan proses finishing packaging seperti menutup kardus dan menempelkan lakban pada kardus, serta menumpuk di tempat penyimpanan yang terdapat di bagian belakang operator. Denah stasiun kerja operator workstation 1 dan 2 dapat dilihat pada Gambar 1.

Pada tahap pengolahan dan analisis, dilakukan pengolahan data yang telah dikumpulkan dengan menggunakan metode OCRA index untuk mendapatkan indeks awal dari metode OCRA dan menentukan nilai evaluasi risiko. Langkah awal dalam melakukan penelitian ini adalah pengumpulan data OCRA index. Data yang dibutuhkan untuk perhitungan OCRA index, meliputi data penentuan tindakan teknis pekerja, waktu kerja, dan kondisi lingkungan kerja.

Langkah berikutnya adalah dilakukan penjadwalan waktu istirahat dengan enumerative algorithm untuk mendapatkan perbaikan sistem kerja. Terakhir, pada penelitian ini dilakukan analisis hasil dengan menghitung kembali OCRA index untuk mengetahui apakah terdapat penurunan risiko atau tidak.

\section{Occupational Repetitive Action (OCRA) Index}

Menurut ISO 11228-3 (2007:15), OCRA index adalah perbandingan rasio antara actual technical action (ATA) atau tindakan teknis aktual dengan reference technical action (RTA) atau tindakan teknis yang direkomendasikan. Prosedur penilaian risiko OCRA terdiri dari tiga langkah dasar, yaitu: (1) menghitung frekuensi teknis tindakan per menit dan jumlah keseluruhan ATA dilakukan dalam shift, menghitung jumlah keseluruhan RTA dalam shift, (2) menghitung OCRA index, dan (3) melakukan evaluasi risiko.

Metode ini mengevalusi empat risiko kolektif utama berdasarkan durasi dari masingmasing faktor tersebut, yaitu: repetitiveness (repetisi), force (gaya), awkward posture and movements (postur dan gerakan yang janggal), dan lack of recovery periods (kurangnya periode istirahat). Selain itu, dalam perhitungan OCRA 
index juga terdapat faktor tambahan lain yang dipertimbangkan, yaitu faktor lingkungan kerja, faktor mekanis, dan faktor organisasional yang terbukti memiliki hubungan kausal dengan upper limb work-related musculoskeletal disorders (UL-WMSDs).

Dalam melakukan perhitungan ATA, terdapat beberapa faktor yang dijadikan sebagai dasar perhitungan. Pertama adalah menghitung jumlah tindakan teknis dalam satu siklus (nTC). Selanjutnya dilakukan evaluasi frekuensi tindakan teknis yang dilakukan per menit $(f)$ dengan mempertimbangkan waktu siklus $(T c)$. Perhitungan frekuensi tindakan teknis yang dilakukan per menitnya diperoleh melalui Pers. [1].

$$
f=n T C \times \frac{60}{T c}
$$

Berikutnya adalah menghitung jumlah keseluruhan tindakan teknis yang dilakukan dalam satu shift ( $n A T A)$ dengan menggunakan Pers. [2], dengan $t$ adalah total waktu kerja operator yang dinyatakan dalam menit.

$$
n A T A=f \times t
$$

Setelah melakukan perhitungan jumlah ATA (nATA), langkah selanjutnya adalah melakukan perhitungan jumlah RTA (nRTA) dengan menggunakan Pers. [3].

$$
\begin{aligned}
& n R T A= \\
& \quad k f \times F_{M} \times P_{M} \times R_{e M} \times A_{M} \times t \times R_{c M} \times t_{M}
\end{aligned}
$$

Dalam melakukan perhitungan jumlah RTA ada beberapa faktor yang dipertimbangkan. Pertama adalah constant frequency $(k f)$ yang merupakan nilai tetapan untuk frekuensi konstan tindakan teknis, yaitu 30. Kedua adalah force multiplier $\left(F_{M}\right)$ yang menggunakan bantuan skala Borg-10, yang dimaksudkan untuk menilai seberapa berat usaha operator dalam melakukan pekerjaannya. Ketiga adalah postural multiplier $\left(P_{M}\right)$ yang didapatkan dari deskripsi postur tubuh dan penilaian gerakan dari empat segmen anatomi, yaitu bahu, siku, pergelangan tangan, dan tangan. Keempat adalah repetitiveness multiplier $\left(R_{e M}\right)$, dimana ketika tugas membutuhkan kinerja tindakan teknis yang sama untuk setidaknya $50 \%$ dari waktu siklus, atau ketika waktu siklus lebih pendek dari 15 detik, $R_{e M}=0,7$. Jika tidak, $R_{e M}=1$. Faktor kelima adalah additional multiplier $\left(A_{M}\right)$ yang didapatkan dari adanya minimal 1 faktor tambahan yang berpengaruh selama pekerjaan berlangsung (meliputi alat bantu, paparan suhu, tingkat kebisingan, dan tingkat pencahayaan).

Tabel 1. Tingkat risiko berdasarkan OCRA Index

\begin{tabular}{cl}
\hline OCRA index value & Level Risiko \\
\hline $0-2,2$ & Tidak berisiko \\
$2,3-3,5$ & Mungkin berisiko \\
$3,6-4,5$ & Risiko rendah \\
$4,6-9$ & Risiko sedang \\
$>9$ & Risiko tinggi \\
\hline
\end{tabular}

Keenam adalah duration of the repetitive task $(t)$ yang merupakan total waktu kerja operator dan dinyatakan dalam menit. Ketujuh adalah recovery multiplier $\left(R_{c M}\right)$ yang diperoleh dari jumlah keseluruhan jam kerja yang berisiko. Faktor terakhir yaitu duration multiplier $\left(t_{M}\right)$ yang didapatkan dari jumlah jam kerja operator.

Setelah dilakukan perhitungan jumlah $A T A$ dan $R T A$, berikutnya dilakukan perhitungan nilai OCRA index sesuai dengan Pers. [4] dan mengevaluasi tingkat risiko sesuai Tabel 1 , yang menjelaskan risk level sesuai dengan nilai OCRA index yang dihasilkan. Menurut ISO 11228-3 (2007: 39), semakin tinggi nilai OCRA index semakin tinggi pula risiko yang ditimbulkan.

$$
O C R A_{\text {index }}=\frac{n A T A}{n R T A}
$$

\section{Model Penjadwalan Waktu Istirahat Optimal}

Secara khusus, waktu istirahat (recovery periods) memiliki dampak yang kuat pada nilai OCRA index. Waktu istirahat merupakan waktu yang memungkinkan pemulihan fungsi muskuloskeletal untuk satu atau lebih banyak otot/kelompok tendon (ISO 11228:3, 2007). Menurut Collombini dan Occhipinti (2005), untuk dapat mengoptimalisasi distribusi waktu jeda, ada beberapa kriteria yang harus dijadikan sebagai pertimbangan, yaitu:

1. Memberikan jeda waktu sebanyak yang memungkinkan, misal 1 kali setelah 50 menit setelah melakukan pekerjaan berulang dengan durasi tidak boleh kurang dari 7-10 menit.

2. Menghindari pemberian waktu jeda selama jam akhir shift kerja.

3. Apabila pada pekerjaan terdapat visual control, maka visual control tersebut juga dapat digunakan sebagai periode pemulihan.

Untuk setiap jam pada pekerjaan yang berulang, metode OCRA menunjukkan bahwa 
sepuluh menit merupakan durasi minimum dari waktu istirahat. Oleh karena itu, menurut Boenzi, dkk. (2013), pada metode OCRA dilakukan observasi per jam untuk menentukan jumlah jam kerja dengan periode pemulihan yang tidak memadai dalam shift kerja.

Boenzi, dkk. (2013) menjelaskan bahwa dengan melakukan penjadwalan yang optimal terhadap waktu istirahat dapat mengurangi risiko terjadinya musculoskeletal diseases tanpa mengurangi tingkat level produksi. Dengan enumerative algorithm, yaitu model integer linier programming, maka dapat dilakukan penjadwalan untuk distribusi waktu istirahat.

Dengan mempertimbangkan jenis shift pekerjaan yang diamati, jika $n$-jam merupakan rentang waktu yang diberikan, maka A adalah waktu total shift pekerjaan tersebut dalam jam, dengan $a_{t}(t=1,2, \ldots, \mathrm{n})$ merupakan waktu istirahat per jamnya (Pers. 5). Selanjutnya, jika istirahat makan siang termasuk dalam shift kerja, maka diberikan slot sama dengan B. Pada metode OCRA, tidak hanya istirahat makan siang yang dianggap sebagai periode pemulihan, tetapi juga jam sebelum dan setelah itu. Waktu istirahat juga dimungkinkan pada satu jam sebelum shift terakhir. Oleh karena itu, langkah pertama adalah menentukan penempatan waktu istirahat makan siang yang optimal untuk memaksimalkan periode pemulihan.

Dalam hal ini, model memberikan batasan untuk tidak meletakkan istirahat makan siang di awal atau akhir dari shift kerja. Oleh karena itu, jika slot waktu $j$ dari shift kerja didefinisikan sebagai berakhirnya slot waktu istirahat makan siang, maka rentang nilai $j(2, \ldots, \mathrm{n}-1)$ ditetapkan.
Selanjutnya, $b_{j-1}$ dan $b_{j}$ didefinisikan sebagai fraksi waktu slot $j-1$ dan $j$ dari shift kerja, termasuk istirahat makan siang, seperti pada Pers. [6]. Pers. [7] merupakan perhitungan nilai lunch, jika istirahat makan siang termasuk dalam waktu istirahat dalam shift pekerjaan.

$$
\begin{aligned}
& \sum_{t=1}^{n} a_{t}=A \\
& \left\{\begin{array}{c}
b_{j-1}+b_{j}=B \\
b_{j-1} \geq 0 \quad ; \forall j(2,1, \ldots, n-1) \\
b_{j}>0
\end{array}\right. \\
& a_{j-1}+b_{j}=\text { Lunch } ; \forall j(2,1, \ldots, n-1)
\end{aligned}
$$

Pada akhirnya, satu jam untuk pekerjaan repetitif membutuhkan waktu pemulihan yang tepat sebesar satu jam, termasuk waktu istirahat minimal sepuluh menit berturut-turut (ISO 11228: 3, 2007).

Oleh karena itu, mengingat keseluruhan durasi sisa waktu istirahat yang diberikan, yaitu $\mathrm{C}$, dan dan dengan asumsi bahwa sisa istirahat diberikan sama panjangnya, yaitu $c_{t}$ untuk setiap $t$, maka langkah berikutnya adalah menentukan semua kombinasi pengalokasian waktu istirahat, sehingga dapat memaksimalkan jumlah jam kerja dengan periode pemulihan yang tepat, seperti pada Pers. [8]. Penentuan waktu istirahat optimal dalam penjadwalan berbasis OCRA index ini harus memaksimalkan jumlah jam kerja dengan periode pemulihan yang memadai dalam shift, sehingga fungsi tujuannya dapat ditulis seperti pada Pers. [9].

$$
\begin{aligned}
& \left\{\begin{array}{c}
c_{t} \geq x_{t} a_{t} / 6 \\
\sum_{t=1}^{n-1} c_{t}=C \quad \\
x_{t} \in\{0,1\}
\end{array} \quad \forall t \neq(j-1, j)\right. \\
& \text { OF } F_{\text {break }}=\max _{\left\{x_{t}, b_{j}\right\}}\left(\sum_{t=1}^{n-1} x_{t}+\text { Lunch }\right)
\end{aligned}
$$

\begin{tabular}{|c|c|c|c|c|c|c|c|c|c|}
\hline \multicolumn{2}{|l|}{$t=$} & 1 & 2 & 3 & 4 & 5 & 6 & 7 & 8 \\
\hline \multirow{10}{*}{ Skenario } & A & $\mathrm{X}$ & $\mathrm{X}$ & $\mathrm{X}$ & & Lunch & & & \\
\hline & B & $\mathrm{X}$ & $X$ & & X & Lunch & & & \\
\hline & $\mathrm{C}$ & X & X & & & Lunch & & $X$ & \\
\hline & D & X & & $X$ & $X$ & Lunch & & & \\
\hline & E & $\mathrm{X}$ & & $\mathrm{X}$ & & Lunch & & X & \\
\hline & $\mathrm{F}$ & $\mathrm{X}$ & & & X & Lunch & & $X$ & \\
\hline & G & & X & $\mathrm{X}$ & X & Lunch & & & \\
\hline & $\mathrm{H}$ & & X & $\mathrm{X}$ & & Lunch & & $\mathrm{X}$ & \\
\hline & I & & X & & $X$ & Lunch & & $\mathrm{X}$ & \\
\hline & $\mathrm{J}$ & & & $\mathrm{X}$ & $\mathrm{X}$ & Lunch & & $X$ & \\
\hline
\end{tabular}

Tabel 2. Jadwal Istirahat yang Optimal 
Tabel 3. Tindakan Teknis dan Waktu Siklus untuk Kegiatan Operator Tiap Workstation

\begin{tabular}{|c|c|c|c|}
\hline Workstation & Tangan Kiri & Tangan Kanan & $\begin{array}{l}\text { Waktu } \\
\text { (detik) }\end{array}$ \\
\hline 1 & $\begin{array}{l}\text { - } \\
\text { Mengambil air mineral dalam } \\
\text { kemasan dari conveyor } \\
\text { Memposisikan air mineral dalam } \\
\text { kemasan ke dalam kardus } \\
\text { Mengambil sekat kardus } \\
\text { Memposisikan sekat kardus } \\
\text { Mendorong kardus } \\
\text { Total }\end{array}$ & $\begin{array}{l}\text { Mengambil kardus } \\
\text { Mengambil air mineral dalam } \\
\text { kemasan dari conveyor } \\
\text { Memposisikan air mineral dalam } \\
\text { kemasan ke dalam kardus } \\
\text { - } \\
\text { Memposisikan sekat kardus } \\
\text { - }\end{array}$ & $\begin{array}{c}0,5 \\
8,4 \\
8,45 \\
\\
0,5 \\
0,5 \\
0,5 \\
\mathbf{2 1 , 7}\end{array}$ \\
\hline 2 & $\begin{array}{l}- \\
\text { Mengambil sedotan } \\
\text { Memasukkan sedotan } \\
\text { Melipat tutup kardus } \\
- \\
\text { Menutup kardus dengan lakban } \\
- \\
\text { Memindahkan kardus air mineral } \\
\text { ke tempat penyimpanan } \\
\text { Total }\end{array}$ & $\begin{array}{l}\text { Mengambil kardus kosong } \\
- \\
\text { Meletakkan kardus kosong } \\
\text { Melipat tutup kardus } \\
\text { Mengambil lakban } \\
\text { Menutup kardus dengan lakban } \\
\text { Meletakkan lakban } \\
\text { Memindahkan kardus air mineral ke } \\
\text { tempat penyimpanan }\end{array}$ & $\begin{array}{c}1 \\
0,5 \\
0,5 \\
2,5 \\
0,5 \\
3,5 \\
0,5 \\
7,6 \\
16,1\end{array}$ \\
\hline
\end{tabular}

Pada saat panjang dari keseluruhan shift dianggap sebesar delapan jam, termasuk tiga kali istirahat selama sepuluh menit dan satu kali setengah jam untuk menempatkan istirahat makan siang, maka memungkinkan terdapat 60 jadwal istirahat sebagai solusi yang optimal, yaitu jadwal istirahat yang menyediakan waktu pemulihan yang sama. Akan tetapi, pada kenyataannya sering kali terdapat beberapa kebijakan perusahaan yang dapat membatasi sejumlah solusi diterima. Sebagai contoh, apabila istirahat makan siang hanya dapat ditempatkan pada slot waktu $j=5,6$, maka dalam hal ini hanya terdapat sepuluh solusi optimal yang dapat diterima, seperti digambarkan pada Tabel 2. Akan tetapi, menurut Boenzi, dkk. (2013), kehadiran beberapa batasan dari organisasi dan produksi justru membuat masalah penjadwalan istirahat lebih mudah untuk dipecahkan dengan enumerative algorithm, karena jadwal istirahat yang optimal diperoleh dengan jumlah terbatas.

\section{HASIL DAN PEMBAHASAN}

Dari pengumpulan data yang telah dilakukan pada masing-masing operator di bagian packaging, selanjutnya dilakukan perhitungan OCRA index. Terdapat beberapa langkah dalam perhitungan OCRA index, yaitu menghitung frekuensi tindakan teknis per menit dan jumlah keseluruhan actual technical action (nATA) yang dilakukan dalam shift, menghitung jumlah keselurahan reference technical action (nRTA), dan menghitung OCRA index, serta melakukan evaluasi risiko. Pada penelitian ini dilakukan perhitungan dari empat operator yang diamati baik pada workstation 1 maupun 2 .

Langkah pertama yang dilakukan adalah menghitung jumlah actual technical action (nATA). Dalam melakukan perhitungan ATA, terdapat beberapa faktor yang dijadikan sebagai dasar perhitungan. Faktor pertama adalah jumlah tindakan teknis (nTC) yang dilakukan oleh operator. Pada operator 1 dan 2 di workstation 1 , terdapat sebanyak 5 tindakan teknis untuk tangan kiri dan 4 tindakan teknis untuk tangan kanan. Sedang pada operator 1 dan 2 di workstation 2, terdapat sebanyak 5 tindakan teknis untuk tangan kiri dan 7 tindakan teknis untuk tangan kanan. Jumlah tindakan teknis ini didapatkan dari hasil analisis penentuan kriteria tindakan teknis.

Untuk waktu siklus $(T c)$ yang dibutuhkan dalam menyelesaikan 1 kali proses packaging, pada operator di workstation 1 dibutuhkan waktu sebesar 21,7 detik dan operator di workstation 2 sebesar 16,1 detik. Waktu ini didapatkan melalui pengukuran kerja secara langsung menggunakan 
bantuan alat stopwatch. Tabel 3 merupakan tabel yang menjelaskan tindakan teknis dan waktu siklus untuk kegiatan operator baik di workstation 1 maupun 2.

Dalam menentukan frekuensi tindakan teknis yang dilakukan per menit (f) digunakan Pers. [1] Sebagai contoh pada operator 1 di workstation 1 diperoleh jumlah frekuensi tindakan teknis sebanyak 13 tindakan teknis per menit untuk tangan kiri dan 11 tindakan teknis per menit untuk tangan kanan. Dengan demikian, jumlah keseluruhan tindakan teknis yang dilakukan dalam satu shift (nATA) yang dilakukan oleh operator 1 di workstation 1 adalah sebanyak 5.460 tindakan teknis untuk tangan kiri dan 4.620 tindakan teknis tangan kanan berdasarkan perhitungan dengan Pers. [2]. Tabel 4 merupakan rekapitulasi perhitungan nilai $n A T A$ untuk 4 operator pada workstation 1 dan 2 dalam 1 shift.

Tabel 4. Rekapitulasi nilai ATA tiap operator dalam 1 shift

\begin{tabular}{cccc}
\hline \multirow{2}{*}{$\begin{array}{c}\text { Work } \\
\text { station }\end{array}$} & Operator & \multicolumn{2}{c}{ Nilai $\boldsymbol{n A T A}$} \\
\cline { 3 - 4 } & & $\begin{array}{c}\text { Tangan } \\
\text { Kiri }\end{array}$ & $\begin{array}{c}\text { Tangan } \\
\text { Kanan }\end{array}$ \\
\hline $\mathbf{1}$ & Operator 1 & 5.460 & 4.620 \\
& Operator 2 & 5.880 & 5.040 \\
$\mathbf{2}$ & Operator 1 & 9.240 & 12.180 \\
& Operator 2 & 9.660 & 13.020 \\
\hline
\end{tabular}

Setelah selesai melakukan perhitungan $n A T A$, langkah kedua adalah melakukan perhitungan jumlah reference technical actions (nRTA) dengan beberapa faktor yang dipertimbangkan. Pada semua operator, nilai tetapan untuk faktor frekuensi konstan $(\mathrm{kf})$ tindakan teknis adalah 30 .

Faktor kedua adalah nilai force multiplier $\left(F_{M}\right)$. Dalam menentukan nilai $F_{M}$ digunakan bantuan skala Borg-10. Penilaian skala Borg-10 didapatkan melalui wawancara yang dilakukan kepada empat operator di bagian packaging. Hasil dari wawancara digunakan untuk menentukan penilaian skala Borg-10. Berdasarkan hasil wawancara tersebut, untuk operator 1 dan 2 di workstation 1 diperoleh nilai $F_{M}$ masing-masing sebesar 0,75 dan 0,85 . Sedangkan pada operator 1 dan 2 di workstation 2 diperoleh nilai $F_{M}$ masing-masing sebesar 0,75 dan 0,85 .

Faktor ketiga adalah nilai postural multiplier $\left(P_{M}\right)$. Berdasarkan hasil analisis, operator 1 dan 2 pada workstation 1 melakukan gerakan siku supinasi dan gerakan tangan palmar grip selama siklus berlangsung atau $3 / 3$ siklus, sehingga nilainya adalah 0,5 . Sedangkan pada workstation 2, diketahui operator 1 dan 2 melakukan gerakan siku supinasi, gerakan tangan hook grip, dan gerakan pergelangan tangan fleksi, selama siklus berlangsung atau $2 / 3$ siklus, sehingga nilai $P_{M}$ adalah 0,7 .

Faktor keempat adalah repetitiveness multiplier $\left(R_{e M}\right)$. Untuk tugas yang dilakukan oleh semua operator, baik di workstation 1 maupun 2, mempunyai nilai repetitiveness multiplier $\left(R_{e M}\right)$ sebesar 0,7 karena pekerjaan yang dilakukan merupakan tindakan teknis yang sama yang membutuhkan $50 \%$ lebih dari total waktu siklus.

Faktor kelima adalah additional multiplier $\left(A_{M}\right)$ yang pengambilan datanya dilakukan secara langsung dengan mengamati tempat penelitian. Faktor ini meliputi data tingkat pencahayaan, suhu ruangan, dan tingkat kebisingan yang masing-masing diambil dengan bantuan alat yaitu lux meter, thermometer ruangan, dan sound level meter. Dari data yang dikumpulkan, hanya faktor kebisingan yang mempunyai nilai diatas standar yang diperbolehkan oleh Keputusan Menteri Tenaga Kerja No. 5 1/KEPMEN/1999 yaitu 85 dBA dengan durasi paparan selama 8 jam, sedangkan pada perusahaan ini mempunyai nilai kebisingan sebesar $91 \mathrm{dBA}$. Untuk faktor cahaya dan temperatur masih sesuai standar yang ditetapkan, yaitu masing-masing 230 lux dan $25,8^{\circ} \mathrm{C}$. Dengan mempertimbangan aspek-aspek tersebut, maka didapatkan nilai sebesar 0,8 untuk semua operator, karena faktor seperti suhu, kebisingan dan pencahayaan berpengaruh selama

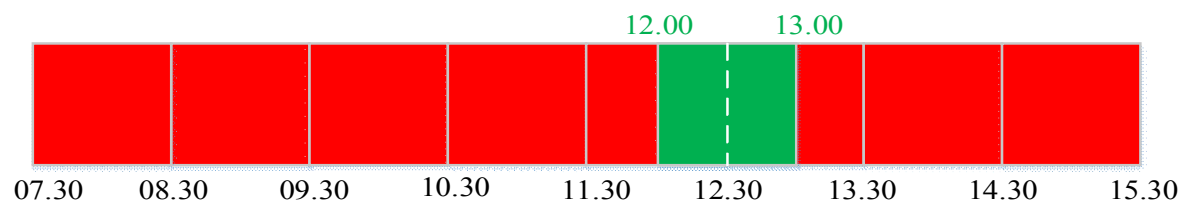

Gambar 2. Jumlah jam kerja yang berisiko 
Tabel 5. Rekapitulasi nilai RTA Tiap Operator dalam 1 Shift

\begin{tabular}{cccc}
\hline \multirow{2}{*}{$\begin{array}{c}\text { Work } \\
\text { station }\end{array}$} & Operator & \multicolumn{2}{c}{ Nilai $\boldsymbol{n A T A}$} \\
\cline { 3 - 4 } & & $\begin{array}{c}\text { Tangan } \\
\text { Kiri }\end{array}$ & $\begin{array}{c}\text { Tangan } \\
\text { Kanan }\end{array}$ \\
\hline $\mathbf{1}$ & Operator 1 & 728 & 728 \\
& Operator 2 & 825 & 825 \\
$\mathbf{2}$ & Operator 1 & 1.019 & 1.019 \\
& Operator 2 & 1.155 & 1.155 \\
\hline
\end{tabular}

Tabel 6. Rekapitulasi Nilai OCRA Index dan Level Risiko Tiap Operator dalam 1 Shift

\begin{tabular}{ccccc}
\hline \multirow{2}{*}{ Workstation } & Operator & \multicolumn{2}{c}{ OCRA Index } & \\
\cline { 3 - 4 } & & $\begin{array}{c}\text { Tangan } \\
\text { Kiri }\end{array}$ & $\begin{array}{c}\text { Tangan } \\
\text { Kanan }\end{array}$ & \\
\hline \multirow{2}{*}{$\mathbf{1}$} & Operator 1 & 7.5 & 6.3 & Berisiko sedang \\
& Operator 2 & 7.1 & 6.1 & Berisiko sedang \\
\multirow{2}{*}{$\mathbf{2}$} & Operator 1 & 9.7 & 11.9 & Berisiko tinggi \\
& Operator 2 & 8.4 & 11.3 & Berisiko tinggi \\
\hline
\end{tabular}

3/3 dari waktu siklus pekerjaan yang dilakukan.

Faktor keenam adalah duration of the repetitive task $(t)$ yang dinyatakan dalam menit. Total waktu kerja pada bagian packaging untuk semua operator adalah selama 7 jam atau 420 menit dalam satu hari kerja.

Faktor ketujuh adalah recovery multiplier $\left(R_{C M}\right)$ yang diperoleh dari jumlah keseluruhan jam kerja yang berisiko. Jumlah jam yang berisiko ditunjukkan pada Gambar 2. Pada Gambar 2 menunjukkan bahwa dari 8 jam kerja terdapat 6 jam yang berisiko (ditunjukkan dengan blok yang berwarna merah penuh). Dengan demikian nilai $R_{C M}$ adalah sebesar 0,25.

Faktor terakhir adalah duration multiplier $\left(t_{M}\right)$ yang didapatkan dari jumlah jam kerja operator. Untuk 7 jam kerja atau 420 menit mempunyai nilai 1,1 sebagai faktor pengali.

Berdasarkan penjabaran 8 faktor tersebut, maka berikutnya dapat dihitung nilai dari keseluruhan jumlah RTA (nRTA) dengan menggunakan Pers. [3]. Sebagai contoh pada operator 1 di workstation 1 diperoleh jumlah keseluruhan tindakan teknis yang direkomendasikan dalam satu shift adalah sebanyak 728 tindakan teknis untuk tangan kiri maupun tangan kanan. Tabel 5 merupakan rekapitulasi perhitungan nilai $n R T A$ untuk 4 operator pada workstation 1 dan 2 dalam 1 shift.

Setelah dilakukan perhitungan jumlah ATA dan RTA, langkah ketiga adalah menghitung nilai
OCRA index sesuai dengan Pers. [4] dan melaksanakan evaluasi risiko. Sebagai contoh pada operator 1 di workstation 1 diperoleh nilai OCRA index untuk tangan kiri adalah sebesar 7,5 dan tangan kanan sebesar 6,3. Tabel 6 merupakan rekapitulasi perhitungan akhir nilai OCRA index untuk 4 operator pada workstation 1 dan 2 dalam 1 shift.

Pada Tabel 6 diketahui bahwa nilai OCRA index yang dihasilkan para operator bagian packaging dapat menimbulkan risiko sedang dan tinggi. Beberapa faktor yang menyebabkan nilai OCRA index sedang dan tinggi adalah jenis pekerjaan dan sistem kerja yang diterapkan. Jenis pekerjaan yang dilakukan tergolong ke dalam jenis pekerjaan yang mempunyai tingkat repetitive yang sangat tinggi. Hal ini dibuktikan dengan waktu siklus yang sangat singkat, yaitu selama 21 detik untuk operator workstation 1 dan 16 detik untuk operator workstation 2, sehingga dalam 1 menit operator dapat melakukan sampai 3 kali siklus kerja.

Hal lain yang mempengaruhi sistem kerja sebagai penyebab nilai level risiko pada OCRA index yang sedang dan tinggi adalah waktu kerja dan prosedur kerja yang diterapkan. Jumlah operator yang dipekerjakan hanya 4 orang, dibagi menjadi 2 orang di workstation 1 dan 2 orang di workstation 2 dan operator bekerja selama 8 jam kerja pada workstation kerja masing-masing dengan waktu istirahat hanyal jam, yaitu pukul 
Tabel 7. Jadwal Istirahat yang Optimal Berdasarkan Studi Kasus

\begin{tabular}{|c|c|c|c|c|c|c|c|c|c|}
\hline \multicolumn{2}{|c|}{$t=$} & 1 & 2 & 3 & 4 & 5 & 6 & 7 & 8 \\
\hline \multirow{6}{*}{ Skenario } & $\mathrm{C}$ & $\bar{X}$ & $\mathrm{X}$ & & & Lunch & & $\mathrm{X}$ & \\
\hline & E & X & & X & & Lunch & & X & \\
\hline & $\mathrm{F}$ & X & & & X & Lunch & & X & \\
\hline & $\mathrm{H}$ & & X & X & & Lunch & & X & \\
\hline & I & & X & & $X$ & Lunch & & X & \\
\hline & $\mathrm{J}$ & & & X & $X$ & Lunch & & X & \\
\hline
\end{tabular}

12.00 s.d. 13.00. Hal tersebut menyebabkan nilai tindakan teknis aktual yang dikerjakan oleh tiap operator dalam 1 shift kerja sangatlah tinggi.

Selain itu, apabila dilihat dari nilai recovery multiplier, rendahnya nilai koefisien dari recovery multipier, yaitu sebesar 0,25, disebabkan karena waktu istirahat yang diberikan belum terdistribusi secara baik. Hal tersebut dapat dilihat dari alokasi pemberian waktu istirahat untuk personal needs, seperti beribadah, makan, buang air, dan fatigue allowance, yang diberikan selama 1 jam penuh hanya di satu titik tertentu (Gambar 2). Sedangkan menurut hasil pengamatan di lapangan, kegiatan personal needs, seperti buang air dan pelemasan tubuh ketika merasa lelah, sering dilakukan pekerja diluar waktu istirahat yang telah diberikan. Oleh karena itu, diusulkan perbaikan melalui penjadwalan waktu istirahat atau waktu jeda yang disesuaikan dengan kebutuhan operator, agar dapat menurunkan nilai level risiko pada perhitungan OCRA index.

\section{Perbaikan dengan Penjadwalan Waktu Istirahat Optimal}

Dalam pengalokasian waktu istirahat yang optimal, langkah pertama yang perlu dilakukan adalah menempatkan waktu istirahat makan siang. Sesuai dengan Gambar 2, waktu istirahat makan siang pada perusahaan ini adalah pada slot waktu $j=(5,6)$ pada satu shift untuk delapan jam kerja. Oleh karena itu, memungkinkan untuk memunculkan 10 alternatif penjadwalan waktu sisa istirahat optimal yang dapat diterima, seperti pada Tabel 2. Akan tetapi, apabila diasumsikan bahwa slot waktu pekerjaan dengan durasi lebih dari dua jam tidak diperbolehkan dan slot waktu kerja yang berlangsung kurang dari 50 menit juga tidak diperbolehkan (Collombini \& Occhipinti, 2005), maka dapat mengurangi jumlah solusi optimal jadwal istirahat yang diterima menjadi enam, seperti ditunjukkan pada Tabel 7.

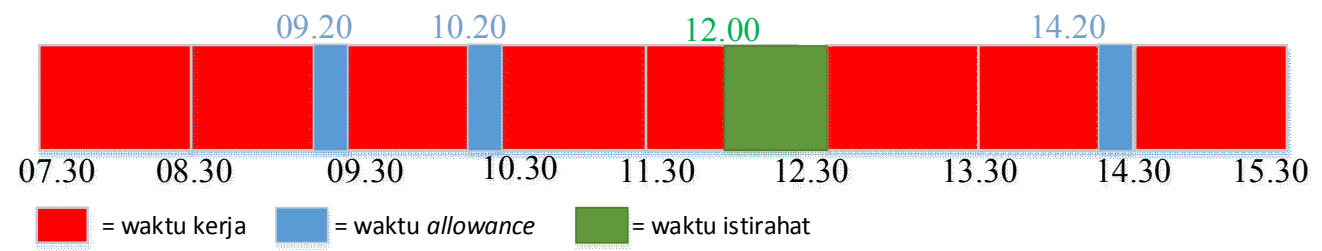

Gambar 3. Usulan pemberian waktu istirahat (waktu allowance) dan istirahat makan siang (waktu istirahat)

Tabel 8. Rekapitulasi Nilai OCRA Index dan Level Risiko Tiap Operator dalam 1 Shift berdasarkan usulan perbaikan

\begin{tabular}{|c|c|c|c|c|}
\hline \multirow[b]{2}{*}{ Workstation } & \multirow[b]{2}{*}{ Operator } & \multicolumn{2}{|c|}{ OCRA Index } & \multirow[b]{2}{*}{ Level Risiko } \\
\hline & & $\begin{array}{c}\text { Tangan } \\
\text { Kiri }\end{array}$ & $\begin{array}{l}\text { Tangan } \\
\text { Kanan }\end{array}$ & \\
\hline \multirow[t]{2}{*}{1} & OP 1 & 4,9 & 5,1 & Berisiko sedang \\
\hline & OP 2 & 4,8 & 5 & Berisiko sedang \\
\hline \multirow[t]{2}{*}{2} & OP 1 & 4,9 & 5,5 & Berisiko sedang \\
\hline & OP 2 & 5,2 & 5,7 & Berisiko sedang \\
\hline
\end{tabular}




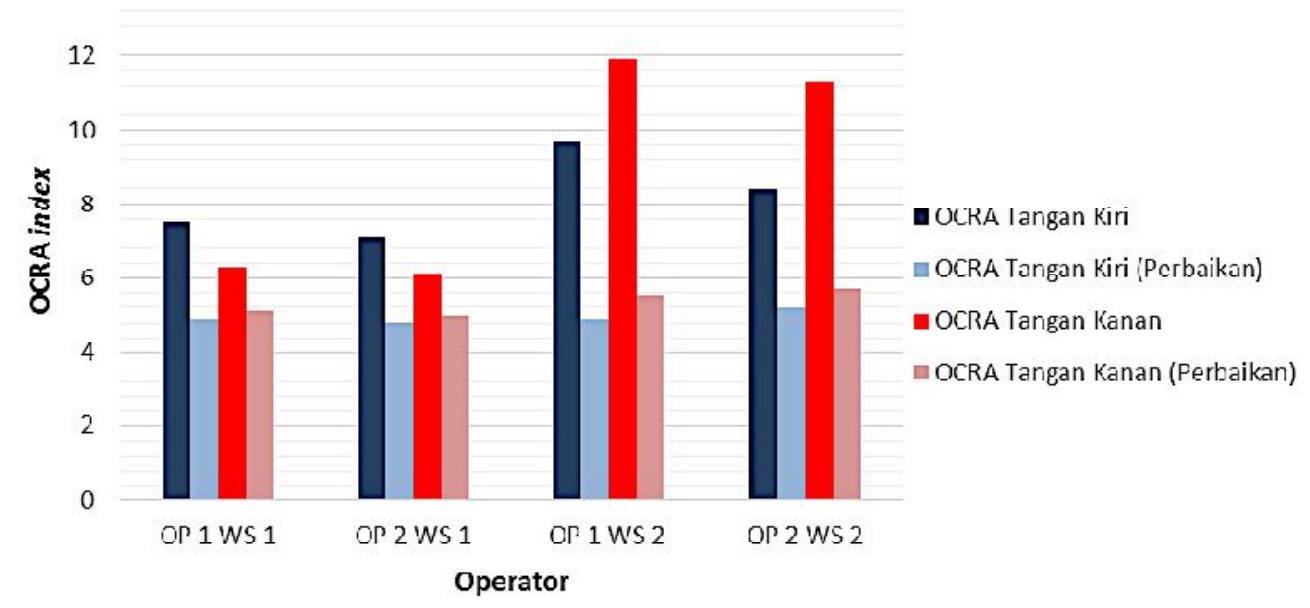

Gambar 4. Grafik perbandingan nilai OCRA index sebelum dan setelah usulan perbaikan

Dengan melihat dari sistem kerja yang diterapkan, pemberian waktu istirahat antara operator workstation 1 dan 2 harus diberikan secara bersamaan, karena pekerjaan antara workstation 1 dan 2 saling berkaitan. Sebagai contoh, dengan skenario $\mathrm{H}$, rencana pengalokasian waktu istirahat yang diberikan adalah selama 10 menit setelah 50 menit bekerja, yaitu pada menit 120 , menit 180 , dan menit 350 . Penjadwalan waktu istirahat dengan skenario ini ditunjukkan pada Gambar 3.

\section{Perhitungan Nilai OCRA Index Setelah Usulan Perbaikan}

Berdasarkan usulan pemberian waktu istirahat dan pengalokasian istirahat makan siang yang tepat, usulan ini dapat mempengaruhi koefisien nilai recovery multiplier pada perhitungan OCRA Index. Nilai recovery multiplier berubah menjadi 0,6 dengan 4 jam kerja yang berisiko dari nilai sebelumnya yaitu sebesar 0,25 dengan 6 jam kerja yang berisiko. Dengan adanya perubahan nilai ini, maka dilakukan perhitungan ulang nilai OCRA index untuk seluruh operator baik pada workstation 1 maupun 2.

Dari hasil perhitungan nilai OCRA Index berdasarkan usulan perbaikan (Tabel 8), terjadi penurunan nilai OCRA index untuk operator 1 pada workstation 1 yaitu menjadi 4,9 untuk tangan kiri dan 5,1 untuk tangan kanan, dari nilai sebelumnya sebesar 7,5 untuk tangan kiri dan 6,3 untuk tangan kanan. Sedangkan nilai OCRA index operator 2 pada workstation 1 menjadi 4,8 untuk tangan kiri dan 5,0 untuk tangan kanan, dari nilai sebelumnya sebesar 7,1 untuk tangan kiri dan 6,1 untuk tangan kanan.

Pada operator 1 workstation 2 didapatkan nilai OCRA index sebesar 4,9 untuk tangan kiri dan 5,5 untuk tangan kanan, dari nilai sebelumnya sebesar 9,7 untuk tangan kiri dan 11,9 untuk tangan kanan. Sedangkan nilai OCRA index operator 2 pada workstation 2 menjadi 5,2 untuk tangan kiri dan 5,7 untuk tangan kanan, dari nilai sebelumnya sebesar 8,4 untuk tangan kiri dan 11,3 untuk tangan kanan. Gambar 4 menunjukkan grafik perbandingan nilai OCRA index semua operator sebelum dan setelah dilakukannya perbaikan penjadwalan jam istirahat.

Dengan demikian, pengaturan ulang waktu istirahat dan pengalokasian istirahat makan siang yang tepat untuk jenis pekerjaan berulang, seperti yang dilakukan oleh operator pada bagian packaging di perusahaan ini, dapat menurunkan risiko cidera yang ditimbulkan. Hasil penelitian ini diharapkan dapat membantu perusahaan dalam mengevaluasi sistem kerja yang digunakan, sehingga dapat mengurangi risiko cidera serta kelelahan yang ditimbulkan akibat sistem kerja yang diterapkan pada bagian packaging.

\section{SIMPULAN}

Berdasarkan perhitungan menggunakan metode OCRA index diketahui, bahwa risiko cidera operator bagian packaging di perusahaan studi kasus ini adalah termasuk dalam level risiko sedang dan tinggi. Faktor yang menyebabkan 
nilai level risiko tersebut adalah masih buruknya distribusi waktu istirahat yang belum sesuai dan waktu bekerja yang terlalu lama untuk jenis pekerjaan yang mempunyai sifat repetitif yang sangat tinggi, meskipun beban kerja yang dialami oleh operator sebenarnya kecil.

Usulan perbaikan yang diberikan untuk penelitian ini adalah didasarkan pada faktorfaktor yang berpengaruh dalam OCRA index yaitu dengan perbaikan alokasi waktu istirahat yang dilakukan dengan carapenjadwalan waktu yang disesuaikan dengan jenis pekerjaan. Penjadwalan waktu istirahat optimal dilakukan dengan enumerative algorithm melalui model integer linear programming yang mampu memberikan jadwal istirahat yang optimal, sehingga dapat mengurangi risiko cidera yang ditimbulkan. Berdasarkan hasil perhitungan nilai OCRA index usulan diketahui terjadi penurunan nilai OCRA index untuk seluruh operator pada workstation 1 dan 2 dibandingkan nilai OCRA index sebelumnya.

\section{DAFTAR PUSTAKA}

Boenzi, F.; Mimmolo, G.; Digiesi, S.; Mossa, G. 2013. "Optimal break and job rotation schedules of high repetitive-low load manual tasks in assembly lines: an OCRA-based approach". Proceedings of 7th IFAC Conference on Manufacturing Modelling, Management, and Control. pp. 1896-1901.

Chiasson, M.E.; Imbeau, D.; Aubry, K.; Delisle, A. 2012. "Comparing the results of eight methods used to evaluate risk factors associated with musculoskeletal disorders". International Journal of Industrial Ergonomics, Vol. 42, pp. $478-488$.

Choi, G. 2009. "A goal programming mixed-model line balancing for processing time and physical workload". Computer \& Industrial Engineering, Vol. 57, pp. 395 400.

ISO 11228-3. 2007. Ergonomic Manual Handling-Part 3 : Handling of Low Loads at High Frequency. Switzerland: ISO.

Marian, R.M.; Luong, L.H.S.; Abhary, K. 2006. "A genetic algorithm for the optimization of the assembly sequences". Computers \& Industrial Engineering, Vol. 50, pp. 503-527.

Mossa, G.; Boenzi, F.; Digiesi, S.; Mimmolo, G.; Romano, V. A. 2016. "Productivity and ergonomic risk in human based production system: A job rotation scheduling model". International Journal of Production Economics, Vol. 171, pp. $471-477$.

Occhipinti, E.; Colombini, D. 2005. The Occupational Repetitive Action (OCRA) Methods: OCRA Index and OCRA Checklist. Florida: CRC Press.

Occhipinti, E.; Colombini, D. 2016. "A toolkit for the analysis of biomechanical overload and prevention of WMSDs: Criteria, procedures and tool selection in a step-by-step approach". International Journal of Industrial Ergonomics, Vol. 52, pp. 18 - 28.

Otto, A.; Scholl, A. 2011. "Incorporating ergonomic risks into assembly line balancing". European Journal of Operational Research, Vol. 212, pp. 277-285.

Prasetyo, E.A. 2010. Analisis Postur dan Gerakan Kerja dengan Mempergunakan Metode Occupational Repetitive Action (OCRA). Skripsi tidak dipublikasikan, Surakarta: Universitas Muhammadiyah.

Roman-Liu, D. 2014. "Comparison of concepts in easy-touse methods for MSD risks assessment". Applied Ergonomics, Vol. 45, pp. $420-427$.

Roossary, E.; Muslim E. 2007."Penerapan metode OCRA untuk pengurangan risiko masalah ergonomi dan muskuloskeletal di workstation packaging detergen PT. X”. Jurnal Teknologi, Vol. 3, pp. 231-239.

Silverstein, B. 2007.Work-Relate Musculoskeletal Disorders of Neck, Back, and Upper Extremity in Washington State. Washington: SHARP.

Sugiyono. 2012. Metode Penelitian Kuantitatif Kualitatif dan $R \& D$. Bandung: Alfabeta.

Xu, Z.; Ko, J.; Cochran, D.J.; Jung, M. 2011. "Design of assembly lines with the concurrent consideration of productivity and upper extremity musculoskeletal disorders using linear models". Computer \& Industrial Engineering, Vol. 62, pp. $431-441$. 